\title{
Use of mineral fertilizer for agricultural leached samples from landfill
}

\section{Flaviano F. De São José (IC), Dailto Silva (PQ), Jorge L. da Paixão Filho (PG), Adriano L. Tonetti (PQ).}

\begin{abstract}
The aim of this study was to determine the mineral formed in the chemical precipitation of ammonia in landfill leachate by X-ray diffraction (XRD), and assess its possible use as an agricultural fertilizer. The main mineral struvite $\left(\mathrm{NH}_{4} \mathrm{MgPO}_{4} \bullet 6 \mathrm{H}_{2} \mathrm{O}\right)$ was found followed by carnallite $\left(\mathrm{KMgCl}_{3} \bullet 6\left(\mathrm{H}_{2} \mathrm{O}\right)\right)$. The latter is a mineral from which it extracts the potassium chloride starting material for the production of fertilizers.
\end{abstract}

Key words: Struvite, carnallite, agriculture

\section{Introduction}

Currently, Brazil imports about $90 \%$ of the potash it uses in agriculture. Finding solutions to meet this demand becomes increasingly necessary. Furthermore, precipitates of landfill leachate can contain significant amounts of minerals that contains in its structure elements used as agricultural fertilizers (nitrogen, phosphorus and potassium $)^{1}$. They were analyzed by X-ray diffraction, 16 samples from an experimental cell installed in municipal solid waste (MSW) landfill Delta The Campinas. The diffraction patterns generated are intended to characterize the material and qualitative analysis of mineral precipitates present.

\section{Results and Discussion}

The analysis experiment was conducted with factorial design with two levels and three factors $(\mathrm{pH}$, molar concentration of magnesium and phosphate) $\left(2^{3}=8\right)$, totaling eight treatments. The assay was performed with phosphoric acid reactants and magnesium oxide. With the precipitated material were performed by powder XRD method in the Geosciences Institute UNICAMP. Previous experiments using magnesium and sodium phosphate hydrogen chloride resulted in the presence of salt $(\mathrm{NaCl})$, which is bad for agriculture ${ }^{2}$. With the reagents used in this test, there was the presence of salt.All diffraction showed the presence of struvite and carnallite. In Figure 1 the characteristic peaks of the two minerals are observed (top) and PDF-2 standards (bottom) used in the analysis.

element. Furthermore, the features struvite phosphorus and nitrogen in its composition, both components used in agricultural fertilization.
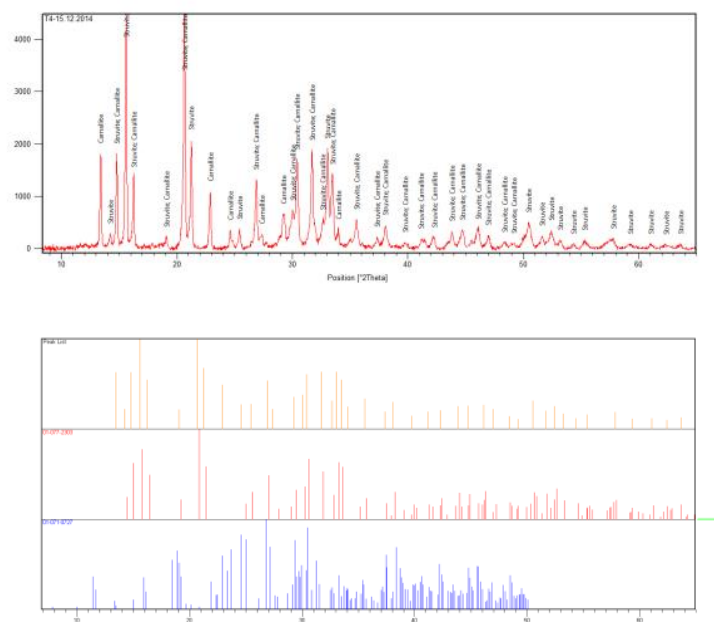

Figure 1. X-ray diffraction for sample T4-15.12.

Potassium is a common element in the earth's crust, but mostly associated with silicates (eg potassium feldspar), and therefore insoluble. The use as a potassium fertilizer is only useful in soluble form. Thus, potassium and magnesium salts are carnallite as important sources of this

\section{Conclusions}

It is concluded that the material has precipitated struvite (potential source of $\mathrm{N}$ and $\mathrm{P}$ ) and carnallite (K source potential).

\section{Acknowledgement}

Thanks to SAE by the exchange and IG UNICAMP by lab availability

\footnotetext{
Massey, M. S.; Davis, J. G.; Ippolito, J. A.; Sheffield, R. R. Agronomy Journal 2009, vol. 101, Issue 2.

2 Noshadi, M., Fahandej, S., \& Sepaskhah, A. R International Journal of Plant Production 2013, 7(2), 295-312,
} 